\title{
Learning and Role of the Family in New Media Environment
}

\author{
Jasmina Vrkić Dimić \\ Department of pedagogy, University of Zadar \\ Obala kralja P. Krešimira IV, br. 2, 23000 Zadar, Croatia \\ Tel: 385-23-200758_E-mail: jvdimic@ unizd.hr \\ Rozana Petani (Corresponding author) \\ Department of pedagogy, University of Zadar \\ Obala kralja P. Krešimira IV, br. 2, 23000 Zadar, Croatia \\ Tel: 385-23-200758Ｅ-mail: rpetani@ unizd.hr \\ Mirela Tolić \\ Department of pedagogy, University of Split \\ Sinjska 2, 21000 Split, Croatia \\ Tel: 385-21-514915Ｅ-mail: mirela.tolic@ ffst.hr
}

Received: February 5, 2012
doi:10.5430/wje.v2n2p85
Accepted: March 12, 2012

Published: April 15, 2012

\begin{abstract}
Media are inseparable from upbringing and education. Different information sources should be a supplement to the basic educational relation between the teacher and students. But, immediate and dialogue based relation between the students and teacher, and between parents and their children, cannot be replaced or suppressed by any type of media interference. The final aim for the students/children is to critically approach information and to achieve their development of independent learning in the ever more complex environment. Our study includes theoretical insights on the specified theme, but also a short empirical research conducted on a sample of high school students $(\mathrm{N}=104)$. The aim was to determine to which extent the students from grammar and vocational high schools believe information they encounter, whether their teachers instruct them to use additional information collected from various electronical and textual sources when solving an educational tasks and whether they are warned of the necessity to check out the information. The aim was also to determine the extent of parent's familiarity with the topics their children confront in various types of sources, frequency of conversations about gathered information with their children and frequency of stimulation to check the information.
\end{abstract}

Keywords: Critical approach, Family role, High school students, Learning, New media environment

\section{New Media Environment}

The contemporary society is distinguished by sophisticated information technology and communication. The new media has gained a manifold role: to inform the young audience, to educate them and create new values. We can say that the media are a significant factor in all spheres of life, mostly in the development of communication. Communication through electronical media has become the main link of the world.

Besides informing and educating all levels of society, the media form new needs of the young generation and draw them near the new forms of communication. Young people easily accept the new technologies and the mentioned changes. Moreover, numerous programs and inventions in the Internet world of communication reveal a far more distinguished involvement of young generations in the creation of new media and life in and with „virtual reality“ (Thomas 1999, 2006). The pedagogical message is that the media have a dominant role in the processes of informing and forming the awareness and behavior of the young generation (Thomas 1999). Media education provides new concepts and forms innovate methods so that the young generation can use the media adequately. It connects diverse scientific views with models of behavior (Baacke 1997). 


\section{Learning and Education - Preconditions of Personal and Social Development}

Learning presents a permanent formative process with the aim of building up an individual's personality. It occurs due to the activities of the individual who is influenced by perceived information. Its outcome is extremely individual, as it is formed in dependence with the individual's experiences and psycho-physiological characteristics. Learning also depends on environmental factors, and can be motivated by them. According to this, formal education plays an essential role. Within this educational frame each individual comes into contact with numerous, diverse and logically structuralized forms of knowledge (Mijatović 1999, Terhart 2001, Meyer 2002). Education is the most important social means for motivating a more profound and harmonious human development (Delors et al. 1998).

Information enables the formation of knowledge; however it cannot be identified with the knowledge. Contemporary media multiply the amount of available information and accelerate the speed of transmission, but guarantee neither efficiency nor logicality. It is essential to develop cognitive and critical thinking skills to reach genuine knowledge. Critical approach towards information is based on learning how to think, doubt, re-examine and on fast adaptation capabilities (Bindé et al. 2007). A qualitative immediate and dialogue based relation between students and teacher cannot be replaced or suppressed by any type of media interference. Different information sources can and should be a supplement to the basic educational relation between the teacher and students.

The classroom activities that teacher initiates and the tasks he assigns to the students have to be intellectually challenging in order to enable the activation of higher level thinking (Becker \& Riel 2000, Dryden \& Vos 2001, Saab et al. 2005). The student is not passive, but actively involved in learning; to learn how to solve a problem - the student has to solve them; to develop critical thinking - the student has to think critically (Doherty et al. 2002). The final aim for the students is to achieve independent learning. In doing so, the development of lifelong learning habits, building up an individual learning style and forming intellectual curiosity is of crucial importance.

\section{The Role of Family in New Media Environment}

The family is the center of a child's life and parents are his first teacher. It is where the child receives its motivation for physical, socioemotional and intellectual development, acquires the culture and value orientations, and where he forms his personality (Petani 2007). In some contemporary families immediate and emotional contact is rare and substituted with the so-called virtual relationship (communication via telephone, sms, e-mail, watching television, etc.), and the feelings of warmth, understanding and mutual support are almost marginalized.

The media are a part of the modern family environment and influence family members in a specific way. Parents are an inevitable media socializer. Researches (Ilišin 2003, Trstenjak 2006, Miliša 2007, Miliša \& Zloković 2008) has revealed the necessity of parents to have discussions with children about contents they have seen or heard. The intention is to assist the children to judge the meaning and comprehend the moral and nature of the provided content (Košir et al. 1999). Nowadays children are very often alone, they watch programs that are not suitable for them, and they are more skilful with digital media than their parents. Parents are not always aware of the need to warn them of the inappropriate topics (Carlsson 2006). Therefore, the parents' role is extremely complex. Optimal parents' approach includes conversations with intention to support children to judge the moral message of the contents they have seen (Ilišin 2003, Petani 2007). The competent parent is sensitive to the children's needs and is able to respond to them in an adequate manner. This parent comprehends the significance of developing partnership with experts who take care of the child and child's education (Maleš 2003). Our task, as experts, is to inform parents and give them a helping hand in their approach towards children.

\section{The Methodology of Research}

\subsection{The aim of research}

The aim of the empirical research was to determine to which extent the young audience believe information from various sources they encounter, whether their teachers instruct them to use additional information collected from various electronical and textual sources and whether they are warned of the necessity to check out the information. Finally, the aim was to determine to which extent the parents are familiar with the topics their children confront in various types of sources, how often they discuss it with them and warn them of the need to test the information.

\subsection{The group of examinees}

The study was conducted in three high schools (1 grammar school and 2 vocational high schools) in Zadar (Republic of Croatia), on a group of 104 third grade high school students. The group of examinees may be regarded as balanced when referring to independent variables. However, as it refers to an only small sample of high school students, it cannot be considered as representative and all of the results will be commented as relevant for the questioned sample. 


\subsection{The instrument of research}

The original questionnaire used for the purpose of the research consists of 6 closed-ended questions, 1 Likert-scale question and 1 open-ended question. The questionnaire was anonymous and the examinees were asked to answer all the questions sincerely and as precisely as possible.

\section{The Analysis and Interpretation of the Research Results}

\subsection{The confidence in information from various sources and the acquaintance to use and check information}

The aim of this section of research is to determine to which extent the high school students believe the information they gain from various information sources (Figure 1).

\section{$<$ Figure 1 about here>}

By calculation of average values it has been confirmed that students believe the information they receive from their schoolbooks the most, and the least in magazines for young people. Although the scale - I mainly believe - was selected the most (which generally proves that students believe the information they receive in most cases), the highest level of criticism was observable towards magazines for young people. $40 \%$ of all examinees do not believe (mainly or not at all) the information from magazines for young people (within this even $42 \%$ answered that they do not believe them at all). A troublesome fact is that $27 \%$ of the examinees do not believe the information from school books (within this percentage $16 \%$ do not believe at all). On the other side, as commented, the high school students express their approval of school books to the highest degree (completely or mainly believe): $73 \%$ of all examinees trust the information from school books (within this percentage $49 \%$ of high school students claim - I believe completely.)

By the observation of the independent variables it has been affirmed that young boys are more critical towards contents from school books than young girls. Students from vocational high schools believe in information from school books more than students from grammar school. Also, students from the city are more critical towards information from school books than the students from villages.

When asked to estimate how frequently their teachers instruct them to find additional information from various electronical and textual sources when solving an educational task (Figure 2), the students claim this occurs occasionally $(53 \%)$. Even $23 \%$ of the students estimate that their teachers never direct them to find additional information sources. However, when all the categories of answers that concern the use of additional sources are added (sometimes, often, always), and are compared with the category- never, there is a proportion of $77 \%: 23 \%$.Therefore, in most cases teachers still instruct their students to use additional sources of information when completing school tasks.

\section{$<$ Figure 2 about here>}

By testing the impact of the followed independent variables no significant differences concerning the examinees`gender, residence or type of high school have been determined.

Students also had to estimate the frequency of the teachers' and parents' warnings on the necessity to check the gathered information from electronical or textual sources (Figure 3).

$<$ Figure 3 about here>

At first sight, one can notice that parents warn their children of the requirement to check information more often than their teachers do. The extreme categories: never and always mainly reflect this fact. When all the categories of answers that support stimulation are added, and compared with the category - never, we get this proportion: $62 \%: 38 \%$ for teachers and $80 \%: 20 \%$ for parents.

Parents and teachers warn the young audience of the requirement to check out information in most cases, and in doing so they stimulate the development of critical awareness. Still, a rather high percentage of students claim that their teachers and parents never worn them of the necessity to examine information. Considerate differences among the students have been defined on the basis of the independent variables. According to the high school students' answers we could conclude that the parents of male children and the parents of children from rural settlements - more often than parents of female children and of students from the urban area - have the tendency never to warn of the necessity to check information from different types of media.

Besides this, the reply referring to: teachers never acquaint to necessity of to checking gathered information - occurs more often with girls and students from grammar school than with boys and students of vocational high schools. We could merely speculate on the reasons of the specified differences, as the represented study was not examining the causes, exclusively the frequency. 
5.2 The parents' familiarity with the contents of various information sources and the frequency of conversations with children about these contents

The intention was to define the extent to which high school students' parents are familiar with the contents that their children encounter in various electronical and textual information sources (Figure 4).

<Figure 4 about here>

The two most common categories of answers were - mainly familiar (46\%) and - mainly unfamiliar (31\%). In this case, however, the sum of all the categories that indicate that parents are (completely or mainly) familiar and of all the categories indicating that the parents are (mainly or completely) unfamiliar with the contents their children encounter in various information sources, results in a proportion of 59\%:41\%. Therefore, just approximately $20 \%$ more students believe that their parents are familiar with the contents. We can conclude that a distressing number of parents (41\%) are completely or mainly unfamiliar with the information their children gain from various sources.

Considering the impact of independent variables, we can observe that parents of female children, grammar school students and students from the urban area are more familiar with the contents their children find in different information sources.

At the very end, the aim was to determine the frequency of conversations that parents have with their children, which refer to the information they encounter in various electronical and textual sources (Figure 5).

$<$ Figure 5 about here>

As observable, half of the examined high school students only sometimes discuss with their parents about the information they gain from the media. A significant fact is that $31 \%$ of students talk to their parents often or always. Therefore, over $80 \%$ of the students still have conversations with their parents which refer to the information from various sources. Nevertheless, we either cannot ignore the relatively high fraction, i.e. 1/5 of students (19\%) who never talk to their parents about this issue.

The impact of independent variables demonstrates that the parents of female children, students from the city and grammar schools discuss the specified contents with their children more often.

\section{Conclusion}

A harmonious life and growing up in a modern era characterized by media pluralism assumes skilfulness in the new life conditions and the use of all conformities they offer. To make this possible, children and young people have to possess a developed critical and creative thinking. Their development is stimulated by using flexible forms of learning based on critical attitude towards information, on activities of solving problems and on making decisions independently. Education directed towards learning how to learn is the precondition to personal and social development. Family and parents have a vital role too. Parents are an inevitable media socializer. The experts' task is to aid and educate parents so that they can perform their parental duty as successfully and responsibly as possible, and so that the parents enable their children to understand the messages from all types of media. Also, the parents can stimulate their children to critically perceive the information and seek for the meaning of the available contents. After the presented theoretical insights and results gained from empirical study, the unquestionable importance of learning, education and family during the children's and young peoples growing up phase is eminent.

\section{References}

Baacke, D. (1997). Medienpädagogik. Tübingen: KoPad Verlag.

Becker, H. J. \& Riel, M. M. (2000). Teacher professional engagement and constructive-compatible computer usage (Report no. 7). Irvine, CA: Teaching, Learning, and Computing. http://www.crito.uci.edu/tlc/findings/report_7/.

Bindé, J. et al. (2007). UNESCO-ovo svjetsko izvješće: Prema društvima znanja. Zagreb: Educa.

Carlsson, U. (2006). Media Regulation, Self-regulation and Education of regulation, Awareness, Empowerment: Young People and Harmful Media Content in Digital Age. Göteborg University: Nordicom.

Delors, J. et al. (1998). Učenje: blago u nama - Izvješće UNESCO-u Međunarodnog povjerenstva za razvoj obrazovanja za 21. stoljeće. Zagreb: Educa. 
Doherty, R. W. et al. (2002). Research Evidence: Five Standards for Effective Pedagogy and Student Outcomes. Tehnical Report No. 1. University of California, Center for Research on Education, Diversity \& Excellence: Santa Cruz. http://gse.berkeley.edu/research/credearchive/pdf/evidence_g1.pdf.

Dryden, G. \& Vos, J. (2001). Revolucija u učenju: kako promijeniti način na koji svijet uči. Zagreb: Educa.

Ilišin, V. (2003). Mediji u slobodnom vremenu djece i komunikacija o medijskim sadržajima. Medijska istraživanja. 9(2), 9-34.

Košir, M., Zgrabljić, N. \& Ranfl, R. (1999). Život s medijima-priručnik o odgoju za medije. Zagreb: Doron.

Meyer, H. (2002). Didaktika razredne kvake: Rasprave o didaktici, metodici i razvoju škole. Zagreb: Educa.

Maleš, D. (2003). Afirmacija roditeljstva. In: Puljiz, V. \& Bouillet, D. (Eds.). Nacionalna obiteljska politika. (pp. 275-302). Zagreb: Državni zavod za zaštitu obitelji, materinstva i mladeži.

Mijatović, A. (1999). Osnove suvremene pedagogije. Zagreb: Hrvatsko pedagoško-književni zbor.

Miliša, Z. (2007). Manipuliranje potrebama mladih. Zagreb: MarkoM.

Miliša, Z. \& Zloković, J. (2008). Odgoj i manipulacija djecom u obiteljima i medijima. Zagreb: MarkoM.

Petani, R. (2007). Samoprocjena kompetentnosti roditelja za roditeljsku ulogu i odabir odgojnih postupaka. Napredak. $1(148), 5-22$.

Saab, N., Van Joolingen, W. R. \& Van Hount-Wolters, B. (2005). Communication in collaborative discovery learning. British Journal of Educational Psychology. 75, 603-621. http://dx.doi.org/10.1348/000709905X42905

Terhart, E. (2001). Metode poučavanja i učenja: Uvod u probleme metodičke organizacije poučavanja i učenja. Zagreb: Educa.

Thomas, A. (1999). Interkulturelle Kommunikation und Koorperation. München: Sylvia Schroll-Machl.

Thomas, A. (2006). Medien und Cultures studies. Göttingen: Studie für Sozialwissenschaft.

Trstenjak, T. (2006). Masovni mediji - poticaj ili smetnja obiteljskom dijalogu. Obnovljeni život. (61)4, 479-488. 


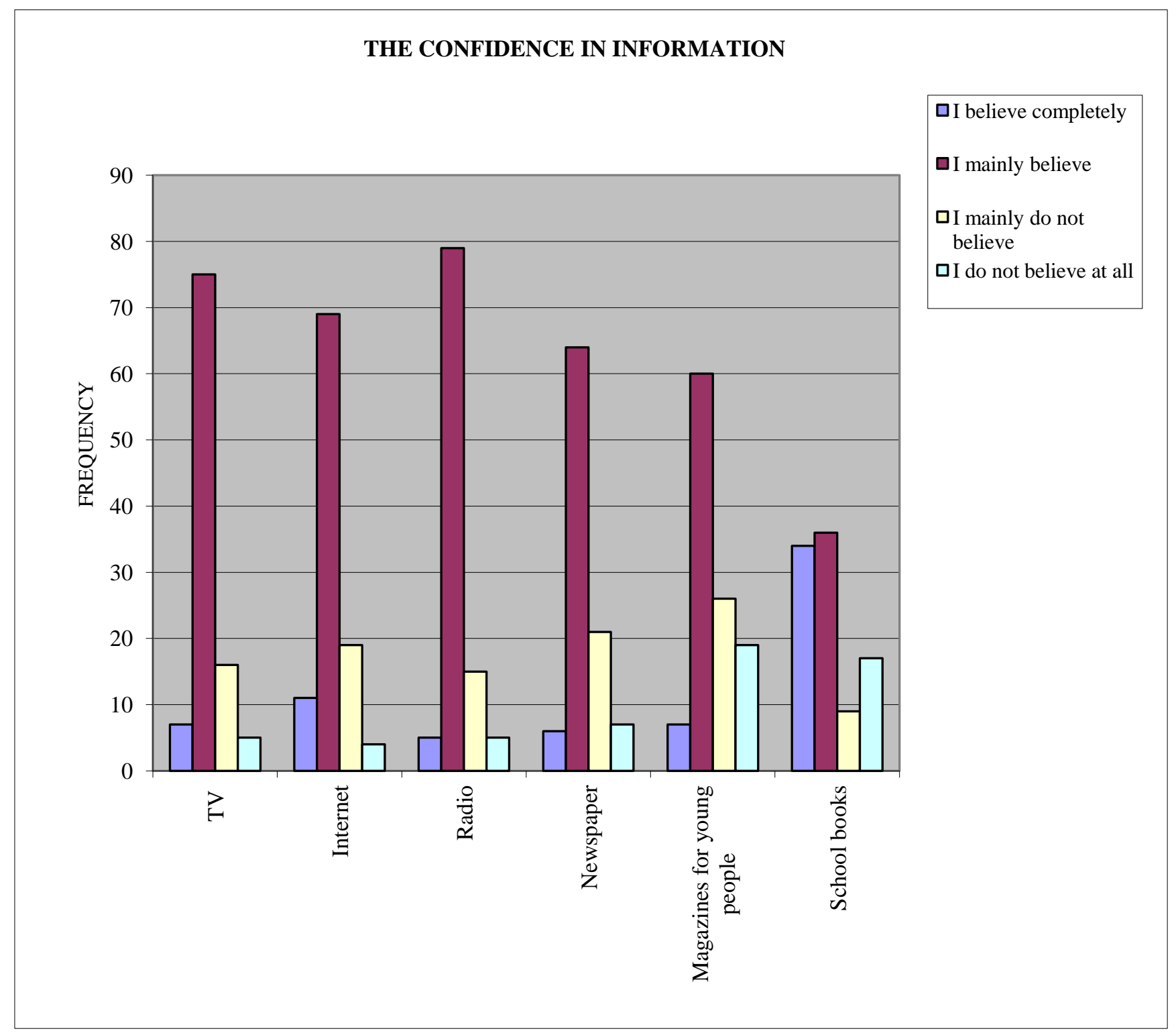

Figure 1. The distribution of answers in regards with the degree of the students`confidence in information from various sources 
TEACHERS - ADDITIONAL INFORMATION SOURCES

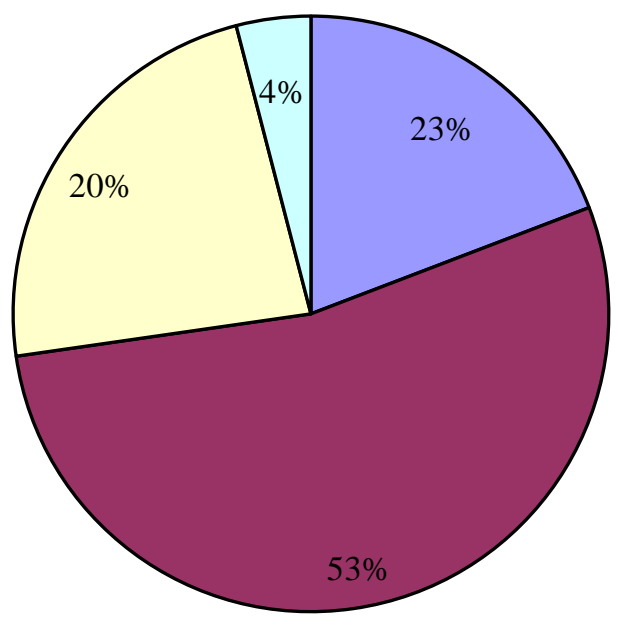

口Never

口Occasionally 口Often

口Always

Figure 2. The frequency of teachers' instructions to use additional information sources 


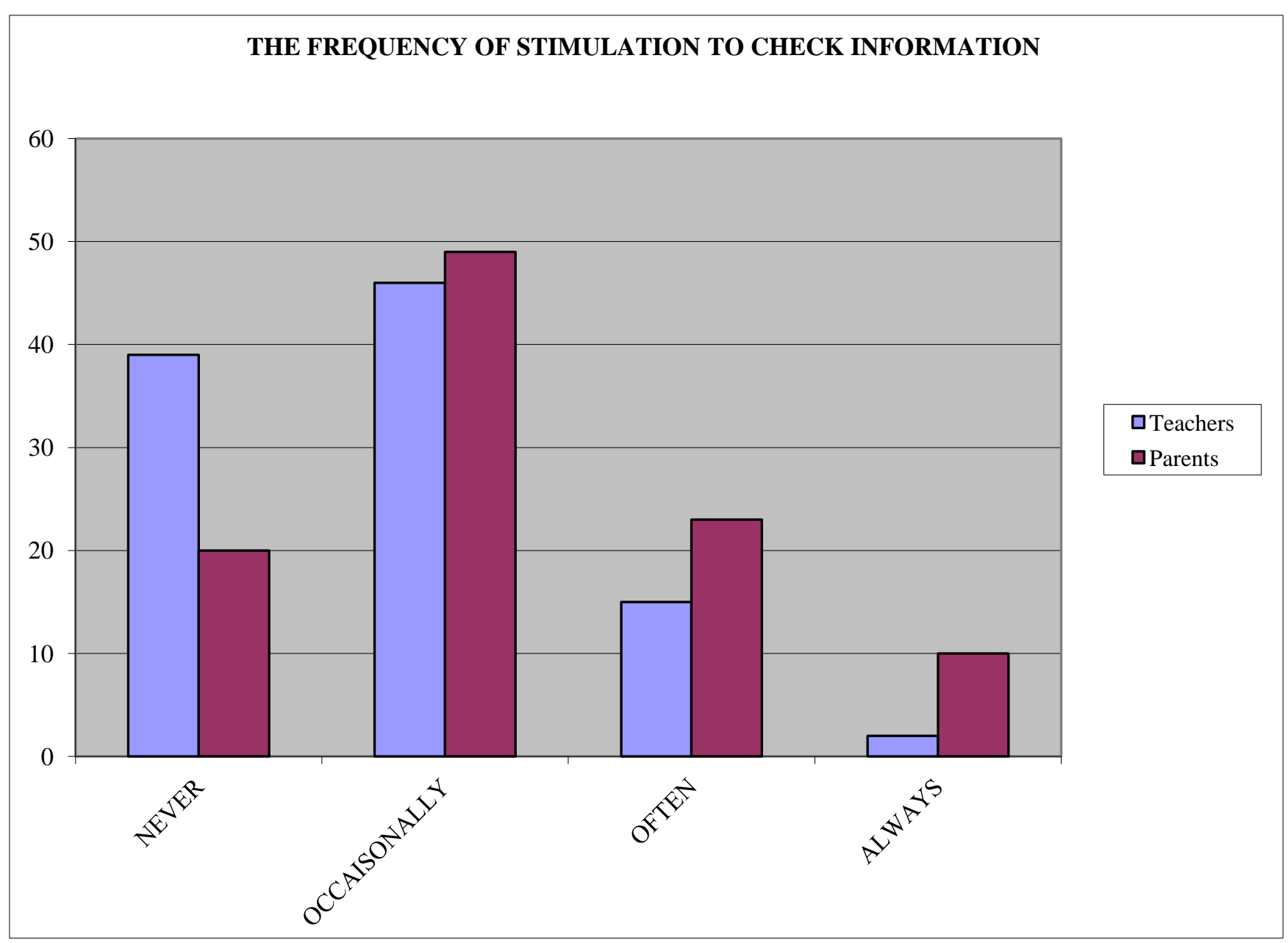

Figure 3. The frequency of stimulation to check information by teachers and parents 


\section{PARENTS - FAMILIARITY WITH THE CONTENTS}

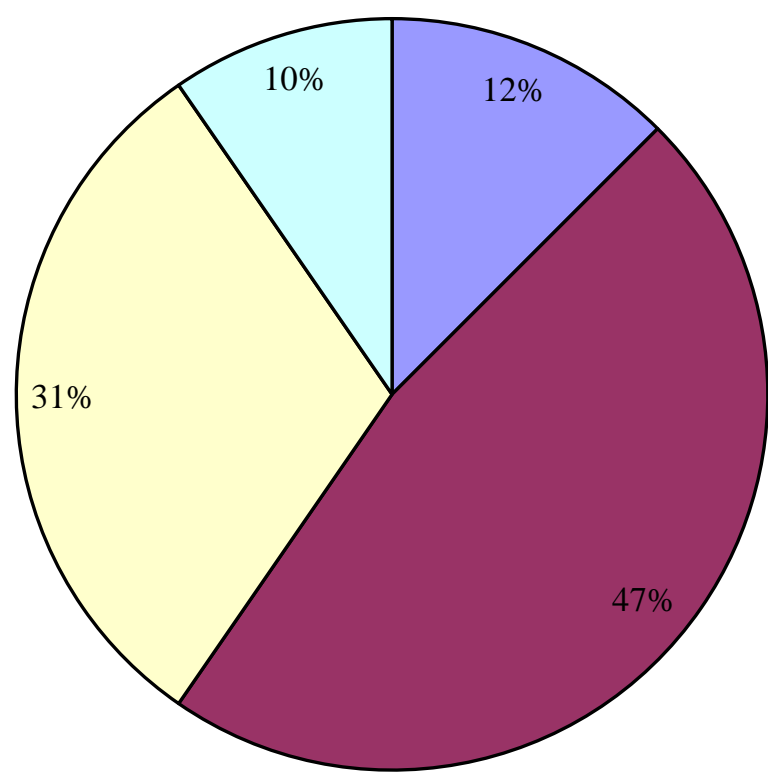

口Completely familiar

$\square$ Mainly familiar

口Mainly unfamiliar

口Completely unfamiliar

Figure 4. The familiarity of parents with the contents that their children encounter in various information sources 
THE FREQUENCY OF CONVERSATIONS WITH PARENTS ABOUT THE CONTENTS

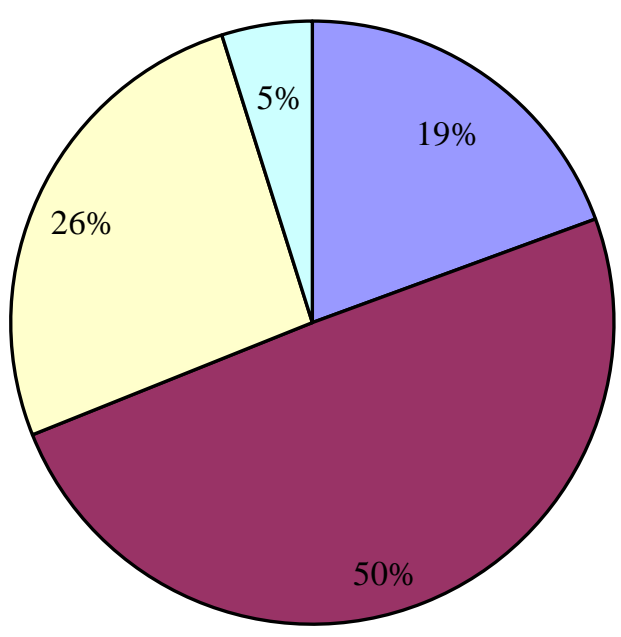

$\square$ Never

$\square$ Sometimes

口Often

口Always

Figure 5. The frequency of conversations with parents about the contents from various information sources 